\title{
Three years in the life of Chief Constable Patrick Kinsela
}

\section{GILLIAN KELLY}

On 3 December 1831 the ship Margaret sailed into Port Jackson carrying Australia's new governor, (Sir) Richard Bourke, his wife and family, his official suite and 40 persons, including servants. ${ }^{1}$ They included 'a few old soldiers who have served with him and now serve him' ${ }^{2}$ and, among their number, probably also as a soldier, was Patrick Kinsela. ${ }^{3}$ A stout and powerful man in the prime of his life, he was single, educated and seemed to move comfortably within the society of New South Wales in the 1830s. It was not until 1835 that he appeared in a public record and by then he was then living at Government House. ${ }^{4}$ Almost nothing is known about Kinsela's biography, apart from three short years when he became, and in many ways characterised, the police presence in the Canberra region. During these years, the last of Kinsela's life, he suddenly comes into focus in the documentary record. By examining his activities as a law officer, as well as his personal life, we can learn much about the region during its very earliest years of colonial settlement. A characteristic of settlement was that officialdom often followed on the heels of the first European incursions into an area. Those such as Kinsela thus faced the task of imposing law and order on a society that, at the time, seemed beyond the reach of government. The challenges he faced in doing so would have broken many, and show that some in the nascent community resisted the imposition of law and order. Yet after three years, and having survived persistent attacks on his character, and the way he went about his role, Kinsela had largely succeeded.

Jane, Kinsela's wife, was born in 1806 in County Cork, daughter of Daniel Mehegan and Mary Thompson, a Protestant family, and of this there is no doubt. On 3 October 1836 she arrived in Sydney on the Duchess of Northumberland, as Mrs Jane Wigmore. ${ }^{5}$ The female immigrants from the ship stayed in temporary quarters at the rear of Government House ${ }^{6}$ until domestic positions could be found for them.

\footnotetext{
Sydney Gazette, 3 December 1831; Kinsela's application to advertise land sales, 10 July 1840.

Sydney Monitor, 9 November 1831, 3.

Application to advertise land in Section 2, Village of Queanbeyan, 11 July 1838. This document states Patrick arrived on the same ship as the late governor, i.e. Richard Bourke on the Margaret.

4 The New South Wales Calendar and General Post Office Directory, 1835.

5 Elizabeth Rushen, Colonial Duchesses: The Migration of Irish Women to New South Wales before the Great Famine (Collins Street East, Vic.: Anchor Books Australia, 2014).

6 Sydney Monitor, 7 October 1836, 3.
} 
In 1835 Kinsela also lived at Government House. ${ }^{7}$ Perhaps this is where they met. The entitlement certificates for the Duchess of Northumberland note that Jane then went to stay with relatives in the colony. ${ }^{8}$ She was certainly joined in Queanbeyan in later years by two sisters and a brother, but the identities of her relatives in the colony in 1836 remain a mystery. Mr Wigmore also remains a mystery. Apart from the 15 months between Jane's arrival and her marriage to Kinsela there is no other reference to the name Wigmore in connection to Jane.

It is possible that Kinsela was also born in County Cork, but there is no evidence that this was so. He was undoubtedly Irish and definitely of the Catholic faith. That he was an educated man with some claim to recognition is reflected in the colonial secretary, (Sir) Edward Deas Thompson, and Captain Alured Faunce, and even local landowners and magistrates James Wright and Terence Aubrey Murray, according him with honorific ' $\mathrm{Mr}$ ' in a time when this was a noted mark of respect. It is likely he was a military man and may have been the Patrick Kinsela who earned a Waterloo Medal in 1816. Alured Faunce, his father-in-law Kenneth McKenzie, Sir Richard Bourke, Joshua John Moore owner of Canberry, Murray's father and father-in-law, as well as James Hartley the runaway, Robert Harvey the signatory to Patrick's records, James Pegg, John Rae and even the father-in-law of both Henry Buckley and Hirst were all military men and many were at Waterloo.

Kinsela may also have been the man from Wexford who served with the 2/40th (Somersetshire) Regiment of Foot. After Waterloo the regiment was escort for convict ships and then was deployed to guard New South Wales and Tasmania between 1823 and 1829, before transfer to India and return to England just in time to have joined the Margaret to New South Wales. He may have belonged to the 21st Regiment, North British Fusiliers, or any of the other regiments connected to the established society of New South Wales and within whose circles he was recognised. The evidence is coincidental, circumstantial and inconclusive but intriguing. ${ }^{9}$ This was an era when people were recognised according to their place in the hierarchy of a class-conscious society. The familial interconnections in the Queanbeyan district were abundant and the acquisition of land paramount. Kinsela's unexplained place in the world seemed to be understood by those who deemed themselves to be the leaders of the community, but apart from those three short years from 1838 to his death in 1841, of Patrick Kinsela it seems there is little more to tell.

7 The New South Wales Calendar and General Post Office Directory, 1835.

8 NSW State Archives, Entitlement Certificates of Persons on Bounty Ships 1832-42, NRS 5314.

9 James Hugh Donohoe, The British Army in Australia 1788-1870: Index of Personnel (Sydney: J. S. Shaw North, 1996); Australian Joint Copying Project War Office, WO 12, Reels 3772-3774, Pieces 5336-5339. 


\section{The district in the 1830s}

The County of Murray was at the extremity of the Nineteen Counties of New South Wales. In the 1830s it was reached only by rough tracks that followed the trails of Aboriginal people and were defined by the passage of horses, carts, bullock wagons and moving stock. The European settlers were mainly overseers for large landholders and convicts who managed the sheep whose wool would make fortunes on the British markets. Very few owners lived in the Limestone Plains area of County Murray and there were none of the facilities that defined European social living: no villages, only a scattering of permanent houses; no shops, churches or schoolsindeed, no women or children - and, overwhelmingly, no immediate officers of the law who could manage the district. The place was developing as a lawless, rough and quite frightening place infested with runaway convicts and sly grog sellers. The climate was hard and, by 1837 , the district was entering an extreme drought of some three years.

Late in 1834 a 'wandering publican' with an extraordinary quantity of rum set himself up on a central station ${ }^{10}$ and sold the alcohol off to assigned servants on the estates around him. This event caused any pretence of authority to disappear, and the resulting unbridled drunkenness motivated the cessation of the shearing season. So severe were the consequences that Robert Campbell, because of the insubordination and loss of control on Duntroon, refused to pay debts accrued by his long-trusted manager, Mr James Ainslie. ${ }^{11}$ In 1835 Ainslie left Duntroon and returned to Scotland, and Charles Campbell, son of Robert, became the manager.

\section{The arrival of the new police magistrate and constable, 1837}

Over the next several years James Wright of Lanyon, Terence Aubrey Murray of Yarralumla station and Robert Campbell of Duntroon made continual representations to the colonial secretary for a police force to be established in the district. In November 1837 Governor Richard Bourke appointed Captain Alured Tasker Faunce as police magistrate at the non-existent village of Queanbeyan. His immediate tasks were to engage the staff who would work in his district and to arrange for buildings in which to house them, hold court and provide a lock-up. Queanbeyan was merely a red square labelled 'Village Reserve' on the map of County Murray. Within that square was a fenced enclave with a store, run by Buckley and

10 Believed to be Klensendorlffe's Elizabeth Farm. Klensendorlffe owned a licensed premise at Tahmoor.

11 Sydney Gazette, 1 January 1835, 3. In the 1830s the title Mr was used to denote a gentleman without other title, and it is significant that Campbell, despite the circumstances, used this title for Ainslie. 
Hirst, Skeate's blacksmith's shop and a scattering of sod huts used by shepherds. Faunce had to look further afield and rented, for the police force, buildings on Canberry station, owned by Joshua Moore, but leased by Murray. ${ }^{12}$ Faunce later described the buildings as sheds that had to be turned into proper huts. ${ }^{13}$ The annual rental to Murray was $£ 50$.

Faunce recommended to the colonial secretary Edward Deas Thompson the appointment of William Hanna as clerk of the bench, Mr Patrick Kinsela as chief constable, James Pegg, free, as lock-up keeper, and James Crossley, Peter Connell and William Jones as ordinary constables. The appointments were to commence on 1 January 1838. Kinsela wrote to the colonial secretary, at Faunce's request, to confirm that Crossley and Connell were free by servitude while William Jones had declined the appointment. Faunce had an unfortunate history in his previous appointment but Bourke had some sympathy for him. The editor of the Sydney Gazette, however, did not share Bourke's attitude and Faunce sued the Gazette for libel, applied for leave from Queanbeyan and remained in Sydney until the end of March while he attended the Supreme Court action he had instigated.

Kinsela meanwhile commenced work on the sheds at Canberry. He employed convict labour cutting poles and stripping bark to repair the roofs and to bolt down the slabs top and bottom to beams securing the buildings as a temporary lock-up and courthouse. He then presented an account to the colonial secretary for the purchase of the necessary hardware, extra rations and soap for the convicts and a fee for a female to clean the courthouse. ${ }^{14}$ The account was rejected because no formal permission had been granted despite Bourke's implied directions to Faunce to do whatever was necessary to provide a courthouse, lock-up and accommodation for the force.

The registers of St Mary's Cathedral, Sydney, record that Patrick Kinsela and Jane Wigmore married in Sydney on 6 February 1838 by Father Charles Lovatt. ${ }^{15}$ Kinsela's signature, witnessed by Lovatt, is a cross mark and the marriage witnesses were Ester and Robert Harvey. ${ }^{16}$ As Kinsela was a literate man and was in Queanbeyan on that date, it is most likely that he and Jane were married in County Murray, the event recorded in Lovatt's notebook and, as was the custom, later transcribed into the formal register of St Mary's, Sydney. The couple lived at Canberry from where Patrick took control of policing, while Faunce was in Sydney pursuing his

12 Index and Registers of Land grants, Lease Moore to Murray, NSW State Archives, Microfilm 229.

13 A. T. Faunce to Colonial Secretary, 6 December 1838, NSW State Archives, 4/2416.

14 Listed were padlocks and keys, staples, hasps and chains, forms, locks and hinges and other unnamed provisions. Faunce to Colonial Secretary, 1 December 1838, NSW State Archives, 38/3223 and following.

15 St Mary's, Sydney, Register of Baptisms, Burials and Marriages, N0 465, Vol. 87-90, Reel 5034, Nowra Library. 16 Patrick was an educated, literate man. This indicates he was not present and either the marriage was performed by proxy or in another place, the ceremony being recorded in an itinerant priest's notes and transcribed. 
defamation action, battling with the court system and the Sydney Gazette. In his absence two unpaid magistrates, Terrence Aubrey Murray and James Wright, sat on the bench.

The first court session convened on 23 February 1838 without the police magistrate, who returned late in March, and this left Kinsela solely in charge of the small and unstable police force. The turnover of ordinary constables was astounding. Kinsela, however, was considered reliable and trustworthy and quickly developed a reputation for his energy in dealing with the recalcitrants. The court system, though, had to deal immediately with the petty crimes of wayward convicts, particularly those assigned to magistrates Wright and Murray. Their punishment for the crimes of insolence, laziness, disobedience, disorderly conduct and neglect of duties was usually a harsh sentence of the lash and provided validation for the necessity of the existence of the court. ${ }^{17}$

\section{Enforcing the rule of law}

Dealing with sly grog shops, runaways and bushrangers were Kinsela's main objectives in creating a safe district. He began by targeting the illegal sales of spirituous liquors, especially at the store of Buckley and Hirst. This, with its associated outbuildings and Skeate's smithy's shop, was the only building within the boundaries of the designated village reserve. As early as 5 February Kinsela found Henry Buckley retailing a quart of wine to convict Samuel Shaw. ${ }^{18}$ He continued to make arrests at the store for the same crime until eventually Buckley and Hirst sold out to John Gray who had financial assistance from Robert Campbell. At the same time, the licensed Elmsall Inn opened in a solid stone house on the perimeter of Duntroon with licensees William Hunt and Joseph Kaye. There was thus now a legal outlet to balance the crackdown on the illegal sale of spirituous liquors.

Within six months, Kinsela had closed down half a dozen grog shops. Establishments at Gundaroo, Bredbo, the Monaro, Stonequarry and Bungendore all closed and the illicit grog was confiscated. He applied to the colonial secretary for compensation of $£ 5$ for each of five successful charges he had brought, with three recalcitrants being charged with one offence of illegally retailing spirits, and another with two. The application included a covering letter signed by Faunce, Wright and Murray, but to no avail. The matter took months to resolve, as it required the attorney-general's opinion as to whether Kinsela was entitled to a share of the government's financial gains that came from his actions. The official advice was that as the prisoners had been unable to pay the fines levied against them, any monies received had to cover

17 Colonial Secretary's letters, convicts and others, Queanbeyan depositions 1838-1844, NSW State Archives, N4/5650.

18 Colonial Secretary's letters, NSW State Archives, N4/5650. 
costs. ${ }^{19}$ Early in 1839 Kinsela (as chief constable) advertised a large quantity of spirituous liquors for sale at the Queanbeyan police offices. Later, Kinsela's detractors alleged that the proceeds of this sale would line his own pockets.

In Kinsela's efforts to maintain order, the pursuit of runaway convicts was equally as important as the closing of grog shops. Runaways posed the problem of increased crime through theft and bushranging as the absconders sought ways to survive. During 1838 and 1839, almost one runaway each week was recaptured and faced the punishment of 50 lashes. By 1840 this had slowed to under 20 for the year. ${ }^{20}$

While Kinsela was not a teetotaller, nor was he immoderate. If this had been the case the Sydney press, fed by local informants, would have used to its maximum damaging effect in its attempts to destroy Faunce, if not Kinsela himself. However, on at least one occasion he threw discretion to the winds. One Alex Weatherhead was overlanding 500 cattle with a team of drovers from the south coast to Adelaide, coming up through Araluen and Braidwood. They camped one evening at Long Swamp and overindulged at Hyland's Inn. Having just settled down for the night the men were disturbed by a very tipsy Kinsela who was on the rampage searching for a runaway. One of the drovers, Henry Benson, did not take kindly to the intrusion and was insolent, causing Kinsela to collar him. Benson threatened to knock his white hat off and no sooner had he uttered the threat than the hat rolled and a scuffle ensued. The gathering was greatly amused as Kinsela was fully clothed with a top coat and Benson wore nought but a shirt, and a very short one at that. Weatherhead split them up but Kinsela foolishly drew his pistol, causing the drovers to join the melee and toss the pistol away. Kinsela returned to the inn where he was staying. The next morning the drovers found the pistol and returned it to Kinsela who wore 'a much bruised face'. Benson was not happy and insisted Kinsela replace his shirt. The matter was eventually settled to apparently everyone's satisfaction with another round of drinks! ${ }^{21}$

In August 1838 Kinsela again recognised a runaway. 'William Peel' was working with William Rusten on Craven, Edward Harrison Cliffe's property next to Yarralumla. In court on 23 October Rusten admitted that he knew 'William Peel' was really James Hartley and that he was a runaway. Hartley was taken into custody and Rusten was charged and found guilty of knowingly harbouring an absconder. The usual punishment for this offence was 50 lashes. The presiding magistrates, Faunce, Murray and Wright, were of the opinion that Rusten was guilty of disorderly conduct and, taking the circumstances into consideration, adjudged him to be

19 Letters from Patrick Kinsela and Magistrates Faunce, Wright \& Murray, memoranda in margins from Deas and Attorney-General, letter from Colonial Secretary to Faunce, Colonial Secretary Letters In and Out, 1838, NSW State Archives.

20 NSW State Archives, Bench record, NRS 3342.

21 Alexander Weatherhead, Leaves from My Life: Being Fifty-Six Years' Experience on the South Coast of New South Wales, Australia (Eden Museum, 1984), 16. 
reprimanded. ${ }^{22}$ Hartley had been harboured by men in that area for several years and Kinsela produced evidence to this effect against Wright, Murray and Charles Campbell. Hartley had been assigned to Robert Campbell's brother-in-law, John Palmer of Parramatta, in 1825. When Charles Campbell went to court, Murray and Wright sat on the bench even though they, too, would face charges for their part in the same offence. This marked a turning point in the relationship between Faunce and Kinsela and Murray and Wright. ${ }^{23}$

When Hartley was taken into custody, he was ill and in need of the medical assistance of Dr Hayley, who presented a bill for $£ 5$. Again the colonial secretary denied it, with some outrage, declaring he was astonished that such a claim had been made and that Faunce had supported it. Faunce's letter was interesting in its subtlety-he suggested that several other persons were implicated in harbouring Hartley and that undoubtedly there would be ample funds to support their cases. ${ }^{24}$

By April 1838 the surveyor James Larmer had drawn up his plan for the first square mile of the village of Queanbeyan. Larmer noted in his field book that Kinsela had applied to have the 10 lots on Monaro Street advertised for sale. ${ }^{25}$ The Government Gazette advertised the blocks in July 1839 and by December Mrs Emma Rowley (née Hunt) owned two of them. An inn and a store were built and by 1840 William Hunt and Joseph Kaye had moved their Elmsall Inn and store from the edge of Duntroon to these buildings, thus making alcohol legally available within the embryonic village.

On 11 December 1838 Kinsela's son, James, was born at 'Cambry' on the Limestone Plains. James was baptised with Murray as his godfather on 3 February 1839 by Bishop Polding. James's obituary recorded that he was born in his father's hut on the capital site. Just two days later, Murray wrote to the colonial secretary requesting a pay rise for Kinsela, in recognition of his performance. ${ }^{26}$

The year 1838 had been an incredibly difficult one with inadequate buildings, especially the lock-up, constant staff changes and the impossible task of recruiting good men into the roles. Hanna, clerk of the bench, had resigned early. By June 1838 Pegg had resigned and was replaced by John O'Connor in whom Kinsela had great hopes, ${ }^{27}$ but he, too, resigned and was replaced by George White who, in turn, was replaced by William Forsyth. John Rae, a free man, left his employment with Murray to become clerk of the bench, but quickly returned to Murray. Kinsela

22 NSW State Archives, Bench record, 23 October 1838, NRS 3342.

23 NSW State Archives, 4/2507; Bruce Moore, The Lanyon Saga (Canberra: Canberra Publishing Co., 1982).

24 NSW State Archives, Deposition Book for Assigned Persons (Queanbeyan Court of Petty Sessions), 1838-44, NRS 3341.

25 Field Book, Plans and Descriptions Queanbeyan, 15 April 1839, James Larmer, Surveyor, NSW State Archives, NRS 13889 item 468.

26 T. A. Murray to Colonial Secretary, 5 February.

27 T. A. Murray to Stewart Mowle, 17 July 1839. 
found himself undertaking the role of clerk of the bench, for which he received an extra $£ 75$ per annum, and later accepted the additional role of keeper of the slaughterhouse. $^{28}$

\section{Hostility of the press}

While Kinsela achieved a measure of success in investigating crimes, capturing criminals, including bushrangers and murderers, and imposing control over illegal grog shops, he achieved little recognition in the press. Its sole purpose where Queanbeyan legal matters were concerned was to print a barrage of false allegations against the local constabulary. Anonymous correspondents aligned with equally anonymous landowners provided scurrilous information, much of it denigrating Kinsela. It began in January 1839 when the Sydney Gazette attacked Queanbeyan's law enforcement team. The editor felt that it would have been remiss for him not to keep an eye on the situation, but distance and the reticence of the local people to inform made proper scrutiny difficult. Until he was certain of his sources, he stated, he would not print a word against anyone involved, but now some reliable anonymous sources had come forward and the editor believed that Governor Gipps had no option but to investigate. ${ }^{29}$

The Sydney Monitor joined the affray with a statement from Marulan asking if it was true that if a ticket-of-leave holder applied to the Queanbeyan court for a conditional pardon the chief constable would object unless he received a fee varying from 10 to 30 shillings. ${ }^{30} \mathrm{~A}$ variation of this complaint was that Kinsela would write petitions for the illiterate, but levy a charge. The Sydney Herald became part of the bandwagon with a letter from a writer who hid behind the nom de plume 'Squat'. He claimed the constables were frequently intoxicated and that one had threatened the utmost violence with a firearm. This same constable was accused of accepting a bribe to present an application for a ticket-of-leave to court. ${ }^{31}$

It was clear that while Faunce was named, the informants and the editors who published the information, no matter how accurate or incomplete, were actually after the chief constable and his team. The charges insinuated that the scourger was often away, among other reasons, looking out for sly grog sellers for the benefit of the chief constable. There was a suggestion that Kinsela only appeared monthly to receive his pay. A horse suspected of being stolen or strayed had been worked continuously and starved by the police to the extent that it died. Another horse was supposedly sold without the required notice being published-the unspoken

28 Government Gazette, 1837-39.

29 Sydney Gazette and New South Wales Advertiser, 22 January 1839, 2.

30 Sydney Monitor and Commercial Advertiser, 14 October 1839, 2.

31 Sydney Herald, 9 March 1840, 2. 
responsibility for lodging those advertisements was Kinsela's. He was further accused of taking Faunce's place as observer of floggings and often reducing the sentence; and further, that culprits who were supposed to have received a flogging often showed no evidence of it happening. In this same vein, an anonymous writer suggested that Kinsela would lessen the severity of a flogging in return for the victim giving sworn evidence favourable to the Crown in particular court cases. There were other issues: the colonial secretary's office refused to appoint and pay a doctor to oversee floggings although Dr William Foxton Hayley was practising in Queanbeyan.

On 18 September 1839 the court finally moved from Canberry to Queanbeyan. The courthouse and lock-up were sited on the flat on the riverbank away from the reach of floods on Faunce's Dodsworth that bordered the Village Reserve. The courthouse was a small detached slab-built hut covered with wooden shingles with a low skillion on one end and plastered inside and out. The lock-up and keeper's room were in the middle of a building of four rooms. A kitchen stood on the lefthand end and a small store on the other, and a slab wall divided the lock-up from the keeper's room. ${ }^{32}$ The government now paid the rent for these official buildings to Faunce.

Late in 1839 Murray travelled to Sydney to appear before an enquiry into policing in the colony. Despite the press allegations, he clearly understood the difficulties of providing an effective police force and alleged that it was neglect at the highest levels, rather than local issues, which compromised police integrity. The lack of suitable buildings was high on his list of grievances. Among other concerns, the size of the local police force was entirely inadequate under any circumstances and if the constables were not escorting prisoners to other places, they were rushing around in different directions issuing subpoenas, as the laws of the day demanded, to those required to appear in court in the next few days. The minutiae of daily policing in the Queanbeyan district did not appear in the reports of this enquiry, but in Queanbeyan this was far from the case. ${ }^{33}$

It was Faunce's responsibility to ensure formal observation of corporal punishments. He delegated this task to Kinsela, who on occasion ordered remissions. This led to assertions in the press that there were corrupt motives behind the remissions. It also led to some of the magistrates ordering assigned servants to strip and show their backs in order to observe the extent of the injuries received. This direct attack on Kinsela so concerned Faunce that he immediately wrote to the colonial secretary saying such practices would lead to insubordination among the convict population.

32 Clerk of Works to Colonial Architect, 18 June 1850, Colonial Secretary letters, NSW State Archives.

33 Sydney Gazette and New South Wales Advertiser, 3 December 1839, 4. 
In January 1840 the full bench of the Queanbeyan magistrates met to discuss the situation. By this time, Murray's brother, James, and Nathaniel Stephen Powell had joined the bench. On 1 February Faunce reported the discussions to the colonial secretary. The local force had been reduced to three men including Kinsela, Connell was the only constable (doubling up as scourger and lock-up keeper) and the pay of 3 shillings and threepence a day was so low that it was impossible to recruit good men. He requested an increase of five ordinary constables and two mounted police, expressing the fear that otherwise the district would be unprotected. ${ }^{34}$ Three days later Wright, citing complaints made about increased neglect of duty and discipline within the police force, called the attention of the bench to the subject. The majority of the bench agreed that the constable (Kinsela) ought to be dismissed. Faunce had other ideas and had the matter adjourned until the following court day. When that day arrived neither Faunce nor Kinsela were present. They had been sighted on the Molonglo Road by one 'Paddy Contract' who reported that Faunce told him Kinsela was 'as worthy and respectable a man as any member of the bench'. ${ }^{35}$

Faunce took leave to visit his family at Liverpool. Wright, Murray and his brother James used his absence to lay charges against the police magistrate. Referring to a lack of discipline within the local force, they claimed procedures were not being followed, and this was exacerbated by Faunce's absolute refusal to work with his fellow magistrates. Nathaniel Powell, the fourth magistrate, was not consulted, nor did he sign the complaints. ${ }^{36}$ Quite incongruously, within weeks, Mr William Edye Manning of the Campbelltown Quarter Sessions also wrote to the colonial secretary suggesting that eight of Wright's convicts had all escaped from Lanyon together and that the matter should be the subject of an enquiry.

\section{An enquiry is convened}

This provided a tipping point, and two highly respected Sydney justices, Charles Windeyer and L. North, were appointed to conduct an enquiry into the administration of justice in the town. The enquiry opened on 15 May 1840 with several weeks allowed for hearings, most of them closed to the public. It was a somewhat farcical but thorough experience with complaint after complaint heard. Witnesses were asked to prove Murray and Wright correct in their interpretations of the situation. Faunce, in giving his evidence, alleged that the justices were after Kinsela, not him, as retribution for Kinsela's charging Wright and Murray with

\footnotetext{
34 Letter dated 1 February 1840.

35 Sydney Herald, 9 March 1840, 9.

36 Letters to Colonial Secretary, Faunce to Colonial Secretary, 19 December 19, 1840, 4/2416, NSW State Archives.
} 
harbouring James Hartley. Faunce claimed that since that event the magistrates had given Kinsela no peace, even though not months before they had been extremely happy with his work to the point of Murray recommending he receive a higher salary.

On 11 June, Justices Windeyer and North presented their decisions to the colonial secretary. They concluded the charges came under three headings. The first concerned a laxity of discipline and here they found Faunce had acted entirely appropriately in each case. There did not appear to be any lack of control and they believed Faunce had done everything possible to maintain strict discipline. The second was the apparent irregularities that had long prevailed in the district and of these Kinsela's demeanour in the courtroom bothered the magistrates most. Windeyer and North concluded that there were differing opinions on the bench, with two dissenting judgements. However, they reported:

From the evidence of suitors attending Court it would certainly appear that the Chief Constable assumed fully as much importance as might be expected from one who probably considered himself, with justice, a zealous and useful, if not favoured, officer. ${ }^{37}$

Of the allegations by the press against Kinsela, only two were discussed: the first being that he ordered the remissions of corporal punishment, with the case of William Williams being cited. Williams was held on consecutive charges, each punishment being 50 lashes. The press said he had received 40 strokes out of the 100 ordered. The Bench Book said he received the full 50 for the first charge, but only 40 for the second. The reason given in the Bench Book was that Kinsela did not believe Williams could bear the last 10 . The other matter was the accusation of Kinsela taking payment from prisoners. No witnesses had been called who could prove this had ever happened but Faunce had not tried to clear the air with the other magistrates on 4 February. While there was no evidence of Kinsela's guilt, it left him open to the accusations in the papers. The third matter was the want of cooperation on the part of Faunce with his fellow magistrates. The justices believed that what the complainants saw as lack of cooperation appeared to them to be reasonable and fair differences of opinion. They concluded that the difficulties could easily have been overcome by there being a better understanding on the bench.

\section{Policing after the enquiry}

And so life moved on. In March 1840 Faunce had formalised what appears to have been an established arrangement with Kinsela. He had a memorial drawn up that leased to Kinsela about 4 acres of land with two or three cottages and outbuildings. This land was bounded by the Queanbeyan River to the west, Faunce's land to

37 Colonial Secretary's Letters Queanbeyan - The Late Commission of Enquiry, Sydney, 11 June 1840. 
the south, Faunce's land and the courthouse to the east and the Village Reserve to the west. There was no rent to be paid by Kinsela but he was responsible for improvements including those already made, with Faunce having the right to resume the property if Patrick did not meet the covenants placed in the agreement. This agreement became Jane's lifeline in just under a year. ${ }^{38}$ In July 1840 Kinsela again applied for land to be advertised for sale-this time on the eastern side of the river, closer to the courthouse and lock-up. The land in question was all the allotments facing Booth Street in Section 2. The request was submitted in Kinsela's name by the same Robert Harvey who witnessed his marriage to Jane; this time all four blocks were sold to Hunt and Kaye.

Towards the end of the year word reached Queanbeyan that the notorious 'Gipsey' Clarke had escaped custody near Bathurst. James Clarke, known as Gipsey, was a true bushranger feared by all who encountered him. He had served some years as an assigned servant in the Queanbeyan district and so had contacts there. He escaped from an escort in early November 1840 and by the end of the month, with the aid of an excellent horse, had insinuated himself back into the Bungendore district, hoping to go unrecognised by the authorities. Magistrate Powell, however, did know Gipsey and sighted him on his property. A message to Queanbeyan brought Kinsela and Corporal Morrison (of the mounted police) to search the property where Clarke was recaptured. Three free men, Toms, Field and John Campbell, and one government man were charged with harbouring him. ${ }^{39}$ Clarke was returned to Sydney in March 1841 and pleaded guilty to being illegally at large with a firearm in his possession. He was sentenced to transportation to a penal settlement for the term of his natural life. The capture was truly a coup for Kinsela. Faunce applied to the colonial secretary for a reward to offset Kinsela's expenses, ${ }^{40}$ but again it was denied because the government received no income from the capture.

\section{The night of 23 February 1841}

Mary, daughter of Kinsela and Jane, was born in Queanbeyan on 5 February 1841. Less than three weeks later, on the evening of 23 February, Kinsela visited William Hunt at his home, the Elmsall Inn, in Monaro Street. They shared an ale but on the word of everyone present, and later Dr Hayley, the men were in no way affected by alcohol. At about 10 o'clock Kinsela and Constable John Scott left in their cart to return to home. It was a moonless and very dark night and Hunt's servant, Henry Lomas, offered Kinsela a lantern, which he declined, saying he preferred to drive in the dark. They crossed the river below the inn and continued east along its edge.

38 Memorial, Lease and Counterpart, 22 March 1840, No. 357 B. R. Faunce to Kinsela; Letter Faunce to J. E. Manning, Registrar, 2 March 1841.

39 Queanbeyan Bench Book 1838-1896, 18 November 1840; Sydney Monitor, 1 December 1840, 2.

40 Letters to Colonial Secretary, Faunce to CS, 19 December 1840. 
Scott warned Kinsela that he was too close to the steep bank and he pulled a little further away, putting the horse to a trot. Scott reminded him of the creek that ran into the river that was difficult to negotiate even in daylight, but it was too late. The cart and horse rolled into the creek bed, pinning both men under it with the horse tangled in the rails and unable to get up.

Scott stated the accident had knocked him out and he had not realised Kinsela was dead. He cooeed for help for some time. William Hunt heard him and responded but when no one appeared, he retired. Scott then started to call 'Murder!' in the hope this would gain more attention than the cooees and he was right. Mrs McKeahnie, living in Gray's complex, ran across the road to Hunt's Elmsall Inn to get help. Hunt and Lomas were joined by storekeeper Edward Cantor and between them they extricated Scott who had crushed ribs. He 'was much hurt and was carried home' ${ }^{41}$ Kinsela, too, was carried home. Young James remembered the distress of his mother when two ticket-of-leave men brought in his father's body. Dr Hayley pronounced that death was caused by a dislocation of the neck, the result of the accidental upsetting of a cart. Kinsela was buried in the small cemetery on the Molonglo River close to The Oaks house.

His death was widely reported. On 4 March the Australasian Chronicle stated:

[Kinsela] was a very active officer, a friend to the poor, and always ready to attend when called on. He had obtained a few enemies for himself by being zealous in the discharge of his duty.

On 9 March the Sydney Herald recorded:

The fate of poor Kinsela was a lamentable one, being snatched off in the prime of life, and in the midst of happiness, leaving a young wife and two infant children to deplore his untimely end, and bewail the loss of a good husband and father. His loss will also be felt in this district, where he had proved himself a diligent and efficient officer of the police, and servant of the public. We regret to say, that it has been insinuated by one or two of the parties, that he was intoxicated at the time of the accident, but this is a falsehood, as the depositions taken before the Police Magistrate will prove. The accident occurred entirely from the bad state of the road and darkness of the night. A verdict of accidental death was recorded.

Then in March, almost three weeks after the accident, the Sydney Gazette printed a letter to the editor:

I have seen a person who has just come from Limestone; he reports that the Chief Constable and another man were killed by the upsetting of a dray in a creek in that neighbourhood; it is said the parties were drunk, but this is contradicted, as Kinsela was a sober man.

41 NSW State Archives, Bench record, NRS 3342. 
The references to intoxication were misleading. It is a certainty that if alcohol was a problem for Kinsela the newspapers, particularly the Sydney Gazette, in their misguided attempts destroy Faunce if not Kinsela himself, would have latched onto such abuse and used it to support their claims of mismanagement in the district.

Kinsela died intestate and, within weeks, Faunce had written to John Edye Manning, the curator of intestate estates, requesting that Jane Kinsela be allowed to manage her own affairs without Manning's interference. He stated that she had land with two or three cottages that could be rented, a few cows and three horses branded in her son's name. There were a few debts both for and against the estate and he believed that if the government took charge then the cost of management would eat up her only means of existence. This letter was supported by a similar one from Sir John Jamison. ${ }^{42}$ As a result Jane was able to continue in her home on the river ${ }^{43}$ with her two very young children until her marriage to William Hunt in 1842.

42 Faunce to J. E. Manning, Registrar, 2 March 1841.

43 NSW Census Queanbeyan, 1841. 
This text is taken from Australian Journal of Biography and History: No. 2, 2019, published 2019 by ANU Press, The Australian National University, Canberra, Australia.

doi.org/10.22459/AJBH.2019.05 